\title{
Diastereoselective auxiliary- and catalyst-controlled intramolecular aza-Michael reaction for the elaboration of enantioenriched 3-substituted isoindolinones. Application to the synthesis of a new pazinaclone analogue
}

\author{
Romain Sallio, Stéphane Lebrun, Frédéric Capet, Francine Agbossou-Niedercorn, \\ Christophe Michon* and Eric Deniau*
}

\section{Full Research Paper}

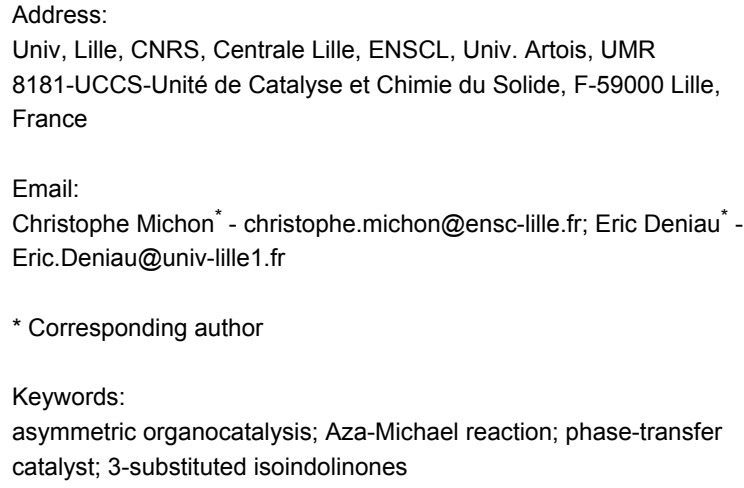

Univ, Lille, CNRS, Centrale Lille, ENSCL, Univ. Artois, UMR 8181-UCCS-Unité de Catalyse et Chimie du Solide, F-59000 Lille, France

Email:

Christophe Michon* - christophe.michon@ensc-lille.fr; Eric Deniau* -

Eric.Deniau@univ-lille1.fr

${ }^{*}$ Corresponding author

Keywords:

asymmetric organocatalysis; Aza-Michael reaction; phase-transfer

catalyst; 3-substituted isoindolinones

\author{
Beilstein J. Org. Chem. 2018, 14, 593-602. \\ doi:10.3762/bjoc. 14.46 \\ Received: 18 December 2017 \\ Accepted: 21 February 2018 \\ Published: 09 March 2018 \\ Associate Editor: M. Rueping \\ (C) 2018 Sallio et al.; licensee Beilstein-Institut. \\ License and terms: see end of document.
}

\begin{abstract}
A new asymmetric organocatalyzed intramolecular aza-Michael reaction by means of both a chiral auxiliary and a catalyst for stereocontrol is reported for the synthesis of optically active isoindolinones. A selected cinchoninium salt was used as phasetransfer catalyst in combination with a chiral nucleophile, a Michael acceptor and a base to provide 3-substituted isoindolinones in good yields and diastereomeric excesses. This methodology was applied to the asymmetric synthesis of a new pazinaclone analogue which is of interest in the field of benzodiazepine-receptor agonists.
\end{abstract}

\section{Introduction}

Isoindolinones I (Figure 1), e.g., 2,3-dihydro-1H-isoindol-1ones, also called phthalimidines are bicyclic lactams whose molecular structure is the basis of a wide range of alkaloids and biologically active compounds [1-11]. Among the latter, optically pure compounds functionalized at $\mathrm{C}-3$ by acetamido groups play an important role as key targets for the pharmaceutical industry. For example, substituted 3-isoindolinones, such as
JM-1232 (II) [12-14] and pazinaclone (III) [15,16] (Figure 1), have shown sedative-hypnotic activities used for the treatment of anxiety by acting as partial agonists at $\operatorname{GABA}_{\mathrm{A}}(\gamma$-aminobutyric acid type A) benzodiazepine receptors [17]. All these studies have highlighted a strong correlation between the compound pharmacological activities and the absolute configurations of their stereocenter [14]. Hence, the asymmetric synthe- 


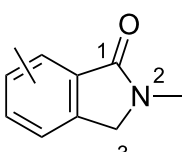

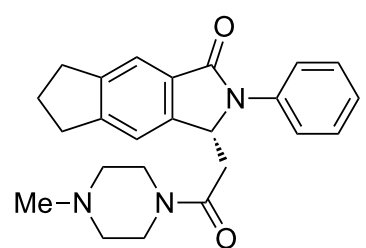

JM-1232 II

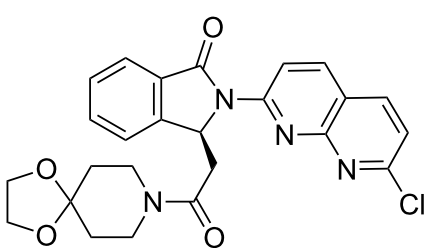

pazinaclone III

Figure 1: Examples of synthetic pharmacologically active chiral 3-substituted isoindolinones.

sis of functionalized 3-substituted isoindolinones using short, versatile and selective procedures is clearly a topic of current interest.

Two strategies can be applied for the asymmetric synthesis of 3 -substituted isoindolinones. First, diastereoselective reactions implying the use of a chiral auxiliary resulted effectively in various optically pure compounds [10,18-20]. Second, enantioselective syntheses of these bicylic lactams were performed by using chiral transition metal- or organocatalysts which control the configuration of the trisubstituted carbon stereocenter alpha to the nitrogen [10,20-34]. Though various metal or organic catalysts were used to promote the aza-Michael reaction in different syntheses for the creation of nitrogen-carbon bonds, phase-transfer catalysts were less studied (see reviews [35-38]) in intermolecular [39-43] and intramolecular [44-46] sequences. Among the latter, a short regio- and stereoselective organocatalyzed intramolecular aza-Michael reaction was reported by us for the asymmetric synthesis of several isoindolinones [20,34]. Indeed, we noticed along our studies some intramolecular azaMichael reactions were effectively catalysed by cinchoninium phase-transfer catalysts (PCT) affording the targeted 3-substituted isoindolinones with promising enantioselectivities (up to 91\%) [20]. However, high enantioselectivities were reached only for specific substitution patterns on the amide nitrogen atom and to a lesser extent on the Michael acceptor. In order to overcome these limitations, we decided to incorporate a chiral auxiliary in our substrates combined with a proper chiral phasetransfer organocatalyst to operate an efficient stereocontrol. To the best of our knowledge such approach involving a double auxiliary and catalyst stereocontrol was never applied before to asymmetric synthesis of enantioenriched isoindolinones.

\section{Results and Discussion Retrosynthetic analysis}

From a retrosynthetic point of view, (3S)-NH free 3-substituted isoindolinones $\mathbf{1}$ and $\mathbf{2}$ could be obtained in high enantioselectivities from the intermediates $(2 R, 3 S)-\mathbf{3}-\mathbf{5}$ after removal of the chiral auxiliary (Scheme 1). (2R,3S)-bicyclic lactams $\mathbf{3}-\mathbf{5}$ could be prepared by the asymmetric intramolecular organo-catalyzed aza-Michael reaction of $(R)$-benzamides $\mathbf{6 - 8}$ bearing an acrylamide group at the ortho-position of the benzene ring.

\section{Synthesis of parent chiral benzamides 6-8}

The use of a stereoselective chiral auxiliary which could be incorporated and removed easily without racemization was crucial for the success of our strategy. These requirements prompted us to incorporate $\alpha$-methylbenzylamine-type chiral auxiliaries, which have been extensively used by Davies et al. to gain access to a wide range of chiral N-heterocycles via intermolecular aza-Michael reactions [34,47-51]. The starting unsaturated benzoic acids $\mathbf{1 4 a}-\mathbf{e}$ and $\mathbf{1 5}$ were readily prepared via a two steps sequence involving first a palladium-catalyzed Heck cross coupling between 2-bromobenzoic tert-butyl esters 9 and 10 with acrylamides 11a-e (69-72\% isolated yields, Scheme 2, Figure 2). The subsequent removal of the $t$-butyl group in esters 12a-e and $\mathbf{1 3}$ (Figure 2) was then achieved by treatment with trifluoroacetic acid to provide in-situ the corresponding benzoic acids 14a-e and 15. The direct coupling of these functionalized carboxylic acids with chiral benzylic primary amines, $(R)$ or

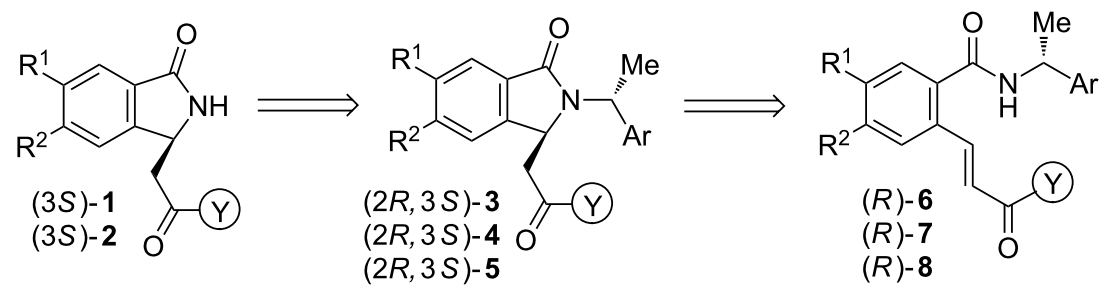



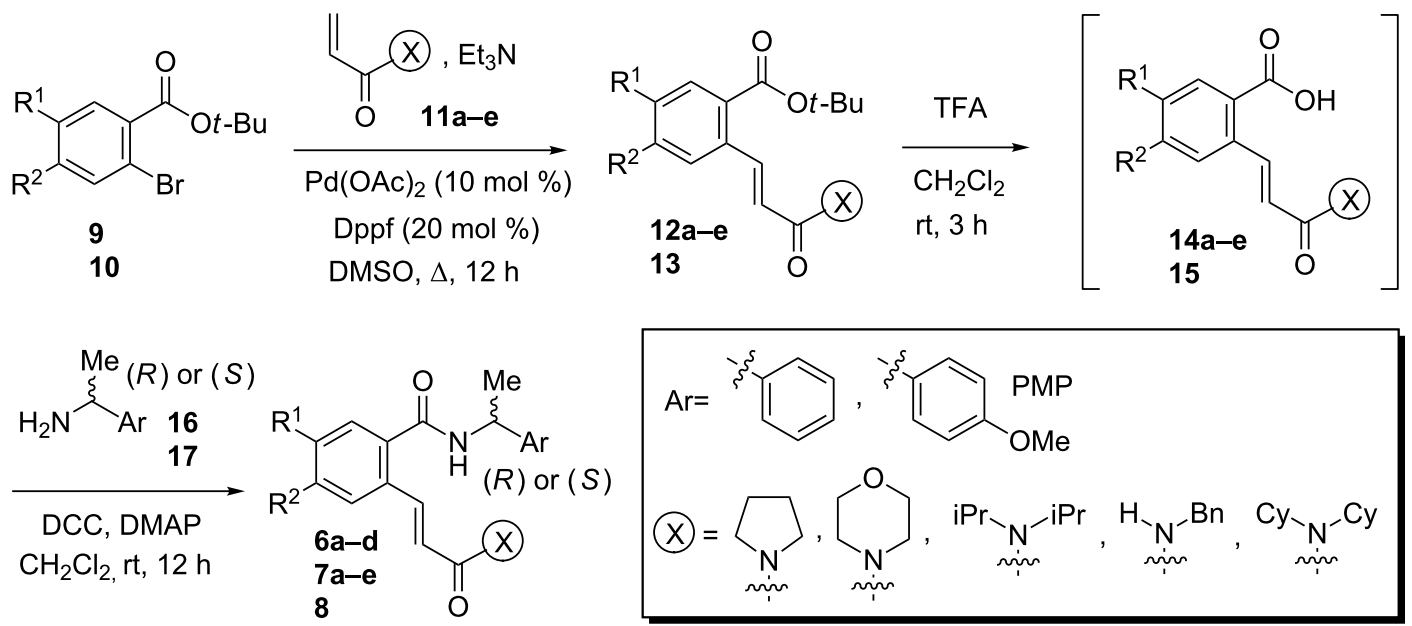<smiles>CCCCCCC(=O)N1CCCC1</smiles><smiles>[R20][14CH2]/C=C/C(=O)NCc1ccccc1C(=O)OCCC</smiles><smiles>CCCCOC(=O)c1ccccc1/C=C/C(=O)N1CCOCC1</smiles><smiles>CCCCOC(=O)c1ccccc1/C=C/C(=O)N(C)C1CCCCC1</smiles><smiles>CCCCC(C)(C)C</smiles><smiles>COC(=O)c1cc(OC)c(OC)cc1/C=C/C(=O)N1CCCC1</smiles>

Figure 2: Esters 12a-e, 13 prepared, isolated yield.

$(S)$-16 $\left(\mathrm{NH}_{2}-\mathrm{CH}(\mathrm{Me}) \mathrm{Ph}\right)$ and $(R)-17\left(\mathrm{NH}_{2} \mathrm{CH}(\mathrm{Me}) p-\mathrm{MeO}-\right.$ $\mathrm{C}_{6} \mathrm{H}_{4}$ ), afforded the required parent amides $6 \mathbf{a}-\mathbf{d}, 7 \mathbf{a}-\mathbf{e}$ and $\mathbf{8}$ in $61-75 \%$ isolated yields after work-up (Scheme 2, Figure 3).

\section{Diastereoselective intramolecular aza- Michael reaction}

First, the study of the diastereoselective intramolecular azaMichael reaction of benzamide substrate $(S)$-6a allowed us to optimize the reaction conditions (Table 1) and latter to screen various privileged phase-transfer catalysts (Figure 4, Table 2). As some aza-Michael reactions were shown to be performed without the use of any catalyst or additional reagent [52-60], we performed control experiments (Table 1). The reaction of reagent $(S)$-6a led to product $(S)$-3a solely by using a base like $\mathrm{Cs}_{2} \mathrm{CO}_{3}$ in toluene with a good yield $(74 \%)$ and a modest diastereomeric excess $(37 \%$ de, Table 1 , entry 1$)$. Increasing the reaction time from $16 \mathrm{~h}$ to $36 \mathrm{~h}$ led to higher diastereomeric excess but no further improvement was noticed with longer reaction times (Table 1, entries 2 and 3). Such chiral amplification versus time was already found to operate through a retroaza-Michael reaction $[61,62]$. Indeed, through an equilibration of aza-Michael and retro-aza-Michael reactions, the minor diastereoisomer of 3a may lead back to a racemic starting material and subsequently favour the major diastereoisomer (Table 1, entries 1-3). The use of a catalytic amount of base led to product 3a in a good yield (Table 1, entry 4 ) but with a loss of diastereoselectivity. Because the optically pure auxiliary and the conjugated ketone were not interacting well, a significant diastereoselectivity could not be obtained and we looked for improvements through the use of an appropriate chiral organocatalyst [63-65]. Indeed, within the same reaction conditions, the use of cinchoninium catalyst $\mathbf{1 8 a}$ afforded isoindolinone 
<smiles>CC(NC(=O)c1ccccc1/C=C/C(=O)N1CCCC1)c1ccccc1</smiles>

(S)-6a, 75\%

(R)-6a, $70 \%$<smiles>CC(NC(=O)c1ccccc1/C=C/C(=O)N1CCOCC1)c1ccccc1</smiles>

(R)-6b, 64\%<smiles>CC(NC(=O)c1ccccc1/C=C/C(=O)N(C(C)C)C(C)C)c1ccccc1</smiles>

(R)-6c, $61 \%$<smiles>CC(NC(=O)c1ccccc1/C=C/C(=O)NCc1ccccc1)c1ccccc1</smiles>

(R)-6d, $66 \%$<smiles>CC(N)C(=O)NC(=O)c1ccccc1/C=C/C(=O)N1CCCC1</smiles>

(R)-7a, $73 \%$

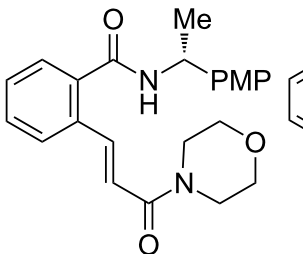

(R)-7b, $72 \%$<smiles>CC(C)C(C)NC(=O)c1ccccc1/C=C/C(=O)N(C(C)C)C(C)C</smiles>

(R)-7c, 68\%<smiles>CC(NC(=O)c1ccccc1/C=C/C(=O)NCc1ccccc1)C(C)(C)C</smiles>

(R)-7d, $61 \%$

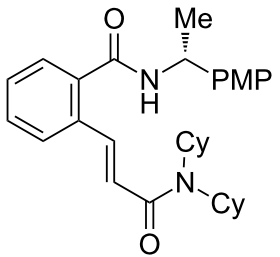

(R)-7e, 66\%<smiles>COc1cc(/C=C/C(=O)N2CCCC2)c(C(=O)NC(C)P)cc1OC</smiles>

8, $72 \%$

Figure 3: Benzamides $6 \mathbf{a}-\mathbf{d}, \mathbf{7 a - e , ~} 8$ prepared, isolated yield.

Table 1: Identification of the optimum reaction conditions for the diastereoselective intramolecular aza-Michael reaction of $(S)-6 a$.<smiles>C[C@H](NC(=O)c1ccccc1/C=C/C(=O)N1CCCC1)c1ccccc1</smiles>

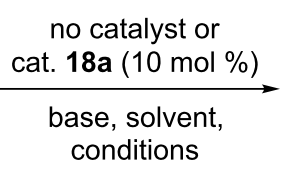

conditions<smiles>CC(c1ccccc1)N1C(=O)c2ccccc2C1CC(=O)N1CCCC1</smiles>

$3 a$

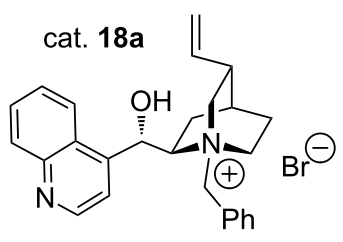

\begin{tabular}{|c|c|c|c|c|c|c|}
\hline entry & catalyst & solvent & base (equiv) & conditions & yield $(\%)^{a}$ & de $(\%)^{b}$ \\
\hline 1 & - & toluene & $\mathrm{Cs}_{2} \mathrm{CO}_{3}(1.3)$ & $\mathrm{rt}, 16 \mathrm{~h}$ & $(2 S)-3 a(74)$ & 37 \\
\hline 2 & - & toluene & $\mathrm{Cs}_{2} \mathrm{CO}_{3}(1.3)$ & $\mathrm{rt}, 24 \mathrm{~h}$ & $(2 S)-3 \mathbf{a}(80)$ & 40 \\
\hline 3 & - & toluene & $\mathrm{Cs}_{2} \mathrm{CO}_{3}(1.3)$ & $\mathrm{rt}, 36 \mathrm{~h}$ & $(2 S)-3 \mathbf{a}(80)$ & $44^{\mathrm{C}}$ \\
\hline 4 & - & toluene & $\mathrm{Cs}_{2} \mathrm{CO}_{3}(0.1)$ & $\mathrm{rt}, 36 \mathrm{~h}$ & $(2 S)-3 a(82)$ & 30 \\
\hline 5 & $18 a$ & toluene & $\mathrm{Cs}_{2} \mathrm{CO}_{3}(1.3)$ & rt, $36 \mathrm{~h}$ & $(2 S)-3 \mathbf{a}(75)$ & 54 \\
\hline 6 & $18 a$ & toluene & $\mathrm{Cs}_{2} \mathrm{CO}_{3}(1.3)$ & $-10^{\circ} \mathrm{C}, 36 \mathrm{~h}$ & $(2 S)-3 a(75)$ & 46 \\
\hline 7 & $18 a$ & THF & $\mathrm{Cs}_{2} \mathrm{CO}_{3}(1.3)$ & $\mathrm{rt}, 36 \mathrm{~h}$ & $(2 S)-3 a(73)$ & 40 \\
\hline 8 & $18 a$ & $\mathrm{CH}_{2} \mathrm{Cl}_{2}$ & $\mathrm{Cs}_{2} \mathrm{CO}_{3}(1.3)$ & $\mathrm{rt}, 36 \mathrm{~h}$ & $(2 S)-3 \mathbf{a}(80)$ & 40 \\
\hline 9 & $18 a$ & toluene & $\mathrm{Ba}(\mathrm{OH})_{2}(1.3)$ & $\mathrm{rt}, 36 \mathrm{~h}$ & $(2 S)-3 a(81)$ & 42 \\
\hline
\end{tabular}

${ }^{a}$ After purification. ${ }^{b}$ Determined by HPLC and ${ }^{1} \mathrm{H}$ NMR. ${ }^{\mathrm{c}}$ No change with longer reaction times.

(S)-3a with higher de (54\%), (Table 1, entry 5). We assumed such de increase resulted from a match effect [65-67] of the diastereomeric ion pair formed by the chiral nucleophile, the conjugated ketone and the cinchoninium salt. Hence, in our case, the chirality of the new stereochemical center was shown to be controlled by both Michael acceptor and donor interacting with the chiral ammonium. Surprisingly, the diastereoselectivity initially obtained for 3a (Table 1, entry 5) was not improved by a decrease of the temperature to $-10{ }^{\circ} \mathrm{C}$ (Table 1 , entry 6 ) or by the use of polar solvents (Table 1 , entries 7 and 8 ) or of another base (Table 1, entry 9).

In order to identify the most active catalyst for the aza-Michael reaction of $(S)$-and $(R)$-6a, an array of phase-transfer catalysts was screened (Figure 4, Table 2). By comparing catalysts 18a and $\mathbf{1 8 b}$, a bromide anion was shown to be preferred to a chlo- 


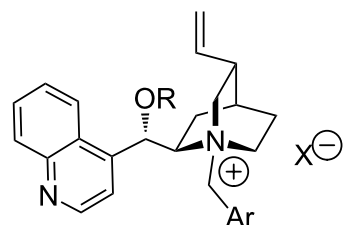

18a $X=B r, A r=P h, R=H$

18b $X=\mathrm{Cl}, \mathrm{Ar}=\mathrm{Ph}, \mathrm{R}=\mathrm{H}$

18c $X=\mathrm{Br}, \mathrm{Ar}=p-t-\mathrm{Bu}-\mathrm{C}_{6} \mathrm{H}_{4}, \mathrm{R}=\mathrm{H}$

18d $X=B r, A r=P h, R=$ allyl

18e $X=I, A r=P h, R=M e$

$18 f \mathrm{X}=\mathrm{Cl}, \mathrm{Ar}=\mathrm{o}-\mathrm{F}-\mathrm{C}_{6} \mathrm{H}_{4}, \mathrm{R}=\mathrm{H}$

$18 \mathrm{gX}=\mathrm{Cl}, \mathrm{Ar}=p-\mathrm{iPr}_{-} \mathrm{C}_{6} \mathrm{H}_{4}, \mathrm{R}=\mathrm{H}$

18h $\mathrm{X}=\mathrm{Br}, \mathrm{Ar}=p-\mathrm{CF}_{3}-\mathrm{C}_{6} \mathrm{H}_{4}, \mathrm{R}=\mathrm{H}$

18i $X=\mathrm{Cl}, \mathrm{Ar}=3,4-$ diMe- $\mathrm{C}_{6} \mathrm{H}_{4}, \mathrm{R}=\mathrm{H}$

18j $\mathrm{X}=\mathrm{Br}, \mathrm{Ar}=3,5$-di- $t-\mathrm{Bu}-\mathrm{C}_{6} \mathrm{H}_{4}, \mathrm{R}=\mathrm{H}$

18k $X=\mathrm{Cl}, \mathrm{Ar}=1$-naphthyl, $\mathrm{R}=\mathrm{H}$

18I $X=\mathrm{Cl}, \mathrm{Ar}=9$-anthracenyl, $\mathrm{R}=\mathrm{H}$<smiles>C=CC1C2CCC1(CCBr)N2CC(O)c1ccnc2ccccc12</smiles>

19<smiles>OCc1ccc(CO)cc1</smiles>

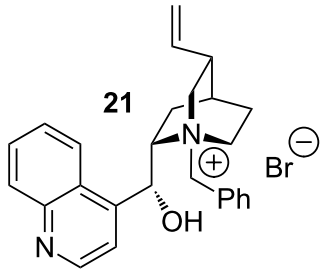<smiles>OCc1cc(CO)cc(CO)c1</smiles>

Figure 4: Phase transfer catalysts (PTC) used in this study.

Table 2: Identification of the most active catalyst for the diastereoselective intramolecular aza-Michael reaction of $(S)$ - and $(R)$-6a.<smiles>O=C(N[C@H]([18OH])c1ccccc1)c1ccccc1/C=C/C(=O)N1CCCC1</smiles>

6a

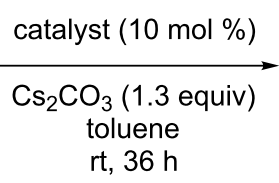<smiles></smiles>

$3 \mathbf{a}$

\begin{tabular}{|c|c|c|c|c|}
\hline entry & reagent & catalyst & yield $(\%)^{a}$ & de $(\%)^{\mathrm{b}}$ \\
\hline 1 & $(S)-6 \mathbf{a}$ & $18 a$ & $(2 S)-\mathbf{3 a}(75)$ & 54 \\
\hline 2 & (S)-6a & $18 b$ & $(2 S)-\mathbf{3 a}(73)$ & 44 \\
\hline 3 & $(S)-6 \mathbf{a}$ & $18 \mathrm{c}$ & $(2 S)-\mathbf{3 a}(77)$ & 62 \\
\hline 4 & $(S)-6 \mathbf{a}$ & $18 d$ & $(2 S)-3 \mathbf{a}(78)$ & 48 \\
\hline 5 & $(S)-6 \mathbf{a}$ & $18 \mathrm{e}$ & $(2 S)-3 \mathbf{a}(75)$ & 42 \\
\hline 6 & $(R)-6 \mathbf{a}$ & $18 a$ & $(2 R)-\mathbf{3 a}(76)$ & 66 \\
\hline 7 & $(R)-6 \mathbf{a}$ & $18 \mathrm{c}$ & $(2 R)-\mathbf{3 a}(75)$ & $80(>96 \%)^{\mathrm{c}}$ \\
\hline 8 & $(R)-6 \mathbf{a}$ & $18 f$ & $(2 R)-\mathbf{3 a}(74)$ & 40 \\
\hline 9 & $(R)-6 \mathbf{a}$ & $18 \mathrm{~g}$ & $(2 R)-\mathbf{3 a}(72)$ & 76 \\
\hline 10 & $(R)-6 \mathbf{a}$ & $18 \mathrm{~h}$ & $(2 R)-3 \mathbf{a}(76)$ & 74 \\
\hline 11 & $(R)-6 \mathbf{a}$ & $18 \mathrm{i}$ & $(2 R)-3 \mathbf{a}(72)$ & 68 \\
\hline 12 & $(R)-6 \mathbf{a}$ & $18 \mathrm{j}$ & $(2 R)-\mathbf{3 a}(74)$ & 60 \\
\hline 13 & $(R)-6 \mathbf{a}$ & $18 k$ & $(2 R)-\mathbf{3 a}(78)$ & 62 \\
\hline 14 & $(R)-6 \mathbf{a}$ & $18 I$ & $(2 R)-3 \mathbf{a}(80)$ & 54 \\
\hline 15 & $(S)-6 \mathbf{a}$ & 19 & $(2 S)-\mathbf{3 a}(71)$ & 34 \\
\hline 16 & $(S)-6 \mathbf{a}$ & 20 & $(2 S)-\mathbf{3 a}(70)$ & 31 \\
\hline 17 & $(R)-6 \mathbf{a}$ & 21 & $(2 R)-\mathbf{3 a}(79)$ & 48 \\
\hline
\end{tabular}

aAfter purification. ${ }^{b}$ Determined by HPLC and ${ }^{1} \mathrm{H}$ NMR. ${ }^{c}$ After flash chromatography on silica gel (EtOAc/hexanes 3:7) and crystallization from hexanes/toluene. Yield: $63 \%$. 
ride one (Table 2, entries 1 and 2). Catalyst 18c para-substituted with a tert-butyl increased significantly the diastereoselectivity of the reaction with $62 \%$ de (Table 2 , entry 3 ).

No de improvements resulted from the use of catalysts $\mathbf{1 8 d}, \mathbf{e}$ which were modified by methylation or allylation of the cinchoninium alcohol fragment (Table 2, entries 4 and 5). While using cinchoninium catalyst $\mathbf{1 8 a}$ and the same reaction conditions, we noticed amide reagent $(R)$-6a led to a higher diastereomeric excess (de) of $66 \%$ for product $(R)$-3a as compared to reagent $(S)$-6a for product $(S)-\mathbf{3 a}$, one configuration being preferred from the other (Table 2, entry 6). A quite similar effect was previously observed in other Michael-additions involving chiral auxiliaries on the nucleophile and on the Michael acceptor [62]. As for (S)-6a, catalyst $\mathbf{1 8 c}$ bearing a bulky tertbutyl group at the benzyl para-position gave the best results in term of stereoselectivity ( $80 \%$ de, Table 2 , entry 7$)$. However, the use of bulkier benzyl, naphthyl and anthracenyl fragments, e.g., catalysts $\mathbf{1 8 i} \mathbf{-} \mathbf{l}$, did not enhance the reaction diastereoselectivity (Table 2, entries 11-14). Whereas catalyst $\mathbf{1 8 f}$ bearing an ortho-fluoro substituent led to a decrease of de (Table 2, entry 8 ), catalyst $\mathbf{1 8 g}$ and $\mathbf{1 8 h}$, respectively, substituted at the benzyl para-position by isopropyl and $\mathrm{CF}_{3}$ groups, gave good results with 76 and 74\% de (Table 2, entries 9 and 10). Dimeric and trimeric organocatalysts $\mathbf{1 9}$ and $\mathbf{2 0}$ based on a cinchonine core did not enhance the reaction diastereoselectivity (Table 2, entries 15 and 16). Finally, by comparison to all the studied cinchoninium catalysts, the use of cinchonidinium catalyst 21 proved to be less efficient with a $48 \%$ de (Table 2, entry 17).

With the optimized reaction conditions in hand, catalyst $\mathbf{1 8 c}$ was employed in the asymmetric intramolecular aza-Michael reaction of benzamides $(R)-\mathbf{6 a} \mathbf{a}-\mathbf{d}$ bearing an array of acrylamide groups (Scheme 3). Substrate 6a bearing a $(R)$ - $\alpha$-methylbenzyl chiral auxiliary led to isoindolinone $3 \mathbf{a}$ in $80 \%$ de and a pure diastereoisomer was recovered after chromatography on silica gel (EtOAc/hexanes 3:7) and crystallization from hexanes/toluene. Reactions of substrates $\mathbf{6 b}-\mathbf{d}$ highlighted the diastereoselection of the reaction was highly dependent of the starting benzamide substitution, 44 to $60 \%$ de being obtained for $\mathbf{3 b}-\mathbf{d}$. Finally, whereas diastereoisomers issued from $\mathbf{6 b}$ could be separated by flash chromatography, this was not possible for products $\mathbf{3 c}$ and $\mathbf{d}$. Cyclisation of chiral benzamides $(R)-\mathbf{7 a}-\mathbf{e}$ and $(R)-8$ led to isoindolinones $(2 R)-\mathbf{4 a}-\mathbf{e}$,<smiles>[R]c1cc(/C=C/C(=O)[O-])c(C(=O)NC([Y19])[Al])cc1[R]</smiles>

$\underset{\substack{\mathrm{Cs}_{2} \mathrm{CO}_{3}(1.3 \text { equiv }) \\ \text { toluene } \\ \text { rt, } 36 \mathrm{~h}}}{\stackrel{18 \mathrm{c}(10 \mathrm{~mol} \%)}{\longrightarrow}}$<smiles></smiles><smiles>CC(c1ccccc1)N1C(=O)c2ccccc2[C@H]1CC(=O)N1CCCC1</smiles>

(2R,3S)-3a, $75 \%$ $80 \%$ de, $(>96 \%)^{a}$<smiles>CC(P)N1C(=O)c2ccccc2C1CC(=O)N1CCOCC1</smiles>

(2R, $3 S)-\mathbf{4 b}, 80 \%$

$75 \%$ de, $(98 \%)^{\text {b }}$<smiles>O=C(C[C@@H]1c2ccccc2C(=O)N1[CH]c1ccccc1)N1CCOCC1</smiles>

(2R,3S)-3b, 78\% $60 \%$ de, $(>96 \%)^{b}$<smiles>CC(C)N(C(=O)CC1c2ccccc2C(=O)N1C(C)C)C(C)C</smiles>

(2R, $3 S)-4 c, 85 \%$

$65 \%$ de, $(98 \%)^{\mathrm{b}}$<smiles>CC(C)N(C(=O)C[C@H]1c2ccccc2C(=O)N1C(C)C)c1ccccc1</smiles>

(2R,3S)-3c, $79 \%$ $56 \%$ de<smiles>CC(c1ccccc1)N1C(=O)c2ccccc2[C@H]1CC(=O)NCc1ccccc1</smiles>

(2R,3S)-3d, $80 \%$ $44 \%$ de<smiles>CC(P)N1C(=O)c2ccccc2C1CC(=O)N1CCCC1</smiles>

(2R, $3 S)-4 a, 82 \%$ $82 \%$ de

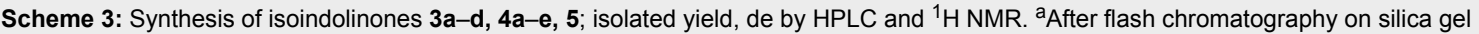
(EtOAc/hexanes 3:7) and crystallization from hexanes/toluene; bafter flash chromatography.on silica gel (EtOAc/hexanes 3:7). 
$(2 R)-5$ in good yields and average to good diastereoselectivities (Scheme 3). In some cases, purification by flash chromatography afforded products $\mathbf{4 b}, \mathbf{4 c}$ and $\mathbf{5}$ in higher diastereomeric purity.

In order to access to the targeted $\mathrm{NH}$-free isoindolinones, the cleavage of the $(R)$ - $\alpha$-methylbenzyl chiral auxiliary was performed in acidic conditions but the reactions proved to be ineffective. However, a change in our models for the more electron rich $(R)$ - $\alpha$-methyl-para-methoxybenzyl group resulted in a straightforward and selective cleavage in mild acidic conditions without racemization (Scheme 4). Indeed, further cleavage of the $\alpha$-methyl-para-methoxyphenyl chiral auxiliary in protected isoindolinones $\mathbf{4 a - c}, \mathbf{4 e}$ and $\mathbf{5}$ resulted in the corresponding $\mathrm{NH}$-free lactams $\mathbf{1 a}-\mathbf{c}, \mathbf{1 e}$ and $\mathbf{2}$ without any racemization (Scheme 4).

A subsequent X-ray analysis of a single crystal allowed us to assert the $(2 R, 3 S)$ configuration of $\mathbf{3 a}$ (Figure 5$)$. This result allowed for the determination of the absolute configurations of all isolated isoindolinones.

\section{Asymmetric synthesis of a new pazinaclone analogue}

With this handful methodology in hands, we then turned our attention to the asymmetric synthesis of a new pazinaclone analogue, which could be of particular interest in the field of benzodiazepine-receptor agonists [8-17]. Indeed, pazinaclone produces its sedative and anxiolytic effects by acting as a partial agonist at $\mathrm{GABA}_{\mathrm{A}}(\gamma$-aminobutyric acid type A) benzodiazepine receptors [17]. In order to circumvent any hydrolysis of the ketal group during the preparation of the starting benzamide

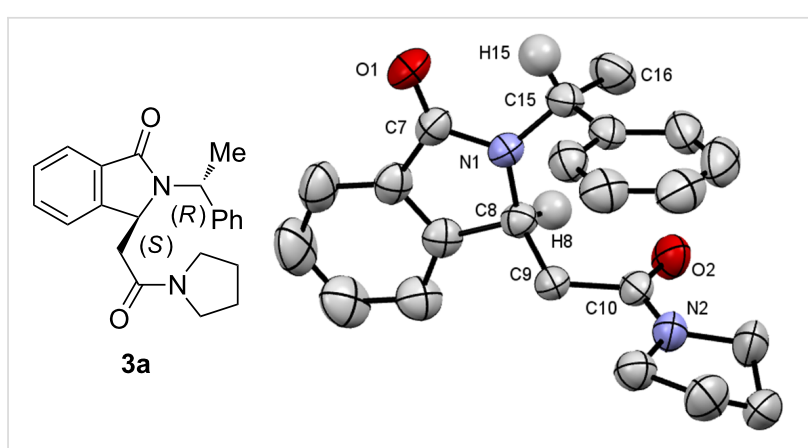

Figure 5: ORTEP plot of isoindolinone (2R,3S)-3a (CCDC 1590565) [68].

(see Supporting Information File 1), the synthesis of intermediate $\mathbf{2 4}$ was performed according another pathway depicted in Scheme 5. Aldehyde $\mathbf{2 3}$ was first readily prepared via a Heck cross coupling reaction between 2-bromobenzaldehyde (22) and acrylamide 11f. Next, a Pinnick oxidation of the aldehyde 23 followed with a coupling reaction with chiral benzylamine $\mathbf{1 7}$ delivered the targeted benzamide $\mathbf{2 4}$ in good yield (65\%).

The intramolecular aza-Michael reaction of acrylamide $(R)-\mathbf{2 4}$ was then performed using the best phase-transfer catalyst $\mathbf{1 8 c}$ and the optimized experimental conditions to give isoindolinone $(2 R, 3 S)-\mathbf{2 5}$ as a mixture of diastereoisomers ( $82 \%$ yield, $71 \%$ de) which were separated by chromatography and purified by crystallization ( $70 \%$ yield, $>96 \%$ de). Lactam $(2 R, 3 S)-\mathbf{2 5}$ bearing a $\alpha$-methyl-para-methoxyphenyl chiral auxiliary was then deprotected with trifluoroacetic acid at room temperature to deliver the $\mathrm{NH}$-free isoindolinone $(3 S)$-26 (76\% yield, $98 \%$ ee) which is a key building block in the synthesis of benzodiazepine-receptor agonists [8-16]. Indeed, the copper-<smiles>[R]c1cc2c(cc1[R])C(CC(=O)O)N(C([Y16])[Y16])C2=O</smiles>

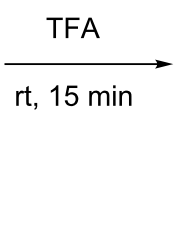<smiles>[R]c1cc2c(cc1[R])C(CC(=O)O)NC2=O</smiles><smiles>O=C1NC(CC(=O)N2CCCC2)c2ccccc21</smiles>

(3S)- $1 \mathrm{a}, 87 \%$ $82 \%$ ee<smiles>O=C1NC(CC(=O)N2CCOCC2)c2ccccc21</smiles>

(3S)-1b, $91 \%$ $98 \%$ ee<smiles>CC(C)N(C(=O)CC1NC(=O)c2ccccc21)C(C)C</smiles>

(3S)-1c, $85 \%$ $97 \%$ ee<smiles>O=C1NC(CC(=O)N(C2CCCCC2)C2CCCCC2)c2ccccc21</smiles>

(3S)-1e, $90 \%$ $67 \%$ ee<smiles>COc1cc2c(cc1OC)C(CC(=O)N1CCCC1)NC2=O</smiles>

(3S)-2, $91 \%$

$95 \%$ ee 
<smiles>O=Cc1ccccc1Br</smiles><smiles>C=CC(=O)N1CCC2(CC1)OCCO2</smiles>

$\mathrm{Pd}(\mathrm{OAc})_{2}(10 \mathrm{~mol} \%)$

$\mathrm{PPh}_{3}(20 \mathrm{~mol} \%)$

toluene, $\Delta, 12 \mathrm{~h}$<smiles>O=Cc1ccccc1/C=C/C(=O)N1CCC2(CC1)OCCO2</smiles>

1) $\mathrm{NH}_{2} \mathrm{SO}_{3} \mathrm{H}, \mathrm{NaClO}_{2}$ THF, $\mathrm{H}_{2} \mathrm{O}$, rt, $48 \mathrm{~h}$

2) $\mathrm{H}_{2} \mathrm{~N} \overbrace{\text { PMP }}^{\mathrm{Me}} 17$

DCC, DMAP

$\mathrm{CH}_{2} \mathrm{Cl}_{2}, \mathrm{rt}, 12 \mathrm{~h}$<smiles>[Y6]C([Y6])NC(=O)c1ccccc1/C=C/C(=O)N1CCC2(CC1)OCCO2</smiles>

(R)-24, 65\%

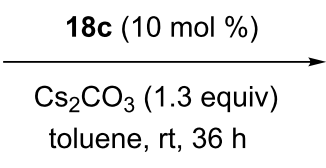

(2R,3S)-25, $82 \%, 71 \%$ de $>96 \%$ de after chromatography and crystallization (yield $=70 \%$ )<smiles>O=C1NC(CC(=O)N2CCC3(CC2)OCCO3)c2ccccc21</smiles>

(3S)-26, 76\%, 98\% ee

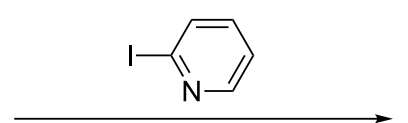

Cul (30 mol \%)

$\mathrm{NH}_{2} \mathrm{CH}_{2} \mathrm{CH}_{2} \mathrm{NMe}_{2}(50 \mathrm{~mol} \%)$

$\mathrm{K}_{3} \mathrm{PO}_{4}$ (1.5 equiv)

dioxane, $100^{\circ} \mathrm{C}, 40 \mathrm{~h}$<smiles>CC(P)N1C(=O)c2ccccc2C1CC(=O)N1CCC2(CC1)OCCO2</smiles>

TFA

rt, 15 min

Scheme 5: Synthesis of pazinaclone analogue (3S)-27

catalyzed $\mathrm{N}$-arylation of $(3 S)$-26 was performed in dioxane with $\mathrm{N}, \mathrm{N}$-dimethylethylenediamine as ligand [27] to deliver the targeted pazinaclone analogue (3S)-27 in a fair yield (66\%) without significant loss in enantiomeric purity. Moreover, it was worth to note compound (3S)-27 was not racemizing when heated in DMF at $150{ }^{\circ} \mathrm{C}$ for $48 \mathrm{~h}$.

\section{Conclusion}

Herein, a new synthetic route towards optically active 3-substituted isoindolinones was developed. These organic compounds are useful for the development of agonists of $\mathrm{GABA}_{\mathrm{A}}$ $(\gamma$-aminobutyric acid type A) benzodiazepine-receptors. Various functionalized isoindolinones were prepared in good yields and diastereomeric excesses by intramolecular aza-Michael reactions using a double stereo-induction approach. The combined use of selected cinchoninium salts as phase-transfer catalysts and of nucleophiles bearing a chiral auxiliary enabled an effective match effect between the diastereomeric ion pair formed by the nucleophile, the Michael acceptor and the cinchoninium salt. Further investigations on this synthetic methodology will be reported in due course.

\section{Supporting Information}

\section{Supporting Information File 1}

File Name S1.pdf.

Experimental procedures, characterization data, copies of the ${ }^{1} \mathrm{H},{ }^{13} \mathrm{C}$ NMR spectra, HPLC chromatograms, ORTEP drawing of $\mathbf{3 a}$ and the summary of $\mathbf{3 a}$ crystallographic information.

[https://www.beilstein-journals.org/bjoc/content/ supplementary/1860-5397-14-46-S1.pdf]

\section{Supporting Information File 2}

File Name S1.cif.

Crystallographic information file of compound 3a. [https://www.beilstein-journals.org/bjoc/content/ supplementary/1860-5397-14-46-S2.cif]

\section{Acknowledgements}

The University Lille 1 is gratefully acknowledged for a $\mathrm{PhD}$ fellowship (R.S). The CNRS, the Chevreul Institute (FR 2638), 
the Ministère de l'Enseignement Supérieur et de la Recherche, the Région Hauts-de-France and the FEDER are acknowledged for supporting and funding partially this work. Mrs Céline Delabre (UCCS) is thanked for GC-MS and HPLC analyses. Dr M. Kouach and Ms A. Descat (Univ. Lille) are thanked for HRMS analyses. Ms M. Dubois (UCCS) and Mrs T. Donne (Dpt Chimie) are thanked for technical assistance. Dr. A. Couture is acknowledged for helpful comments on the manuscript.

\section{ORCID ${ }^{\circledR}$ iDs}

Stéphane Lebrun - https://orcid.org/0000-0001-6227-6668 Frédéric Capet - https://orcid.org/0000-0002-8832-5381 Francine Agbossou-Niedercorn - https://orcid.org/0000-0002-8453-0492 Christophe Michon - https://orcid.org/0000-0002-0138-2923 Eric Deniau - https://orcid.org/0000-0002-3755-4782

\section{References}

1. Wrobel, J.; Dietrich, A.; Woolson, S. A.; Millen, J.; McCaleb, M.; Harrison, M. C.; Hohman, T. C.; Sredy, J.; Sullivan, D. J. Med. Chem. 1992, 35, 4613-4627. doi:10.1021/jm00102a016

2. Pigeon, P.; Decroix, B. Tetrahedron Lett. 1996, 37, 7707-7710. doi:10.1016/0040-4039(96)01738-8

3. Couture, A.; Deniau, E.; Grandclaudon, P. Tetrahedron 1997, 53, 10313-10330. doi:10.1016/S0040-4020(97)00680-7

4. Couture, A.; Deniau, E.; Grandclaudon, P.; Hoarau, C. J. Org. Chem. 1998, 63, 3128-3132. doi:10.1021/jo972247t

5. Belliotti, T. R.; Brink, W. A.; Kesten, S. R.; Rubin, J. R.; Wustrow, D. J.; Zoski, K. T.; Whetzel, S. Z.; Corbin, A. E.; Pugsley, T. A.; Heffner, T. G.; Wise, L. D. Bioorg. Med. Chem. Lett. 1998, 8, 1499-1502. doi:10.1016/S0960-894X(98)00252-2

6. Couture, A.; Deniau, E.; Grandclaudon, P.; Hoarau, C. Tetrahedron 2000, 56, 1491-1499. doi:10.1016/S0040-4020(00)00067-3

7. Riedinger, C.; Endicott, J. A.; Kemp, S. J.; Smyth, L. A.; Watson, A.; Valeur, E.; Golding, B. T.; Griffin, R. J.; Hardcastle, I. R.; Noble, M. E.; McDonnel, J. M. J. Am. Chem. Soc. 2008, 130, 16038-16044. doi:10.1021/ja8062088

8. Di Mola, A.; Palombi, L.; Massa, A. Curr. Org. Chem. 2012, 16, 2302-2320. doi:10.2174/138527212803520254

9. Speck, K.; Magauer, T. Beilstein J. Org. Chem. 2013, 9, 2048-2078. doi:10.3762/bjoc.9.243

10. Di Mola, A.; Palombi, L.; Massa, A. Targets Heterocycl. Syst. 2014, 18, 113-140.

11. Liu, C.; Zhang, Q.; Li, H.; Guo, S.; Xiao, B.; Deng, W.; Liu, L.; He, W. Chem. - Eur. J. 2016, 22, 6208-6212. doi:10.1002/chem.201600107

12. Uemura, S.; Fujita, T.; Sakaguchi, Y.; Kumamoto, E. Biochem. Biophys. Res. Commun. 2012, 418, 695-700. doi:10.1016/j.bbrc.2012.01.080

13. Nishiyama, T.; Chiba, S.; Yamada, Y. Eur. J. Pharmacol. 2008, 596, 56-61. doi:10.1016/j.ejphar.2008.07.054

14. Kanamitsu, N.; Osaki, T.; Itsuji, Y.; Yoshimura, M.; Tsujimoto, H.; Soga, M. Chem. Pharm. Bull. 2007, 55, 1682-1688. doi:10.1248/cpb.55.1682

15. Hussein, Z.; Mulford, D. J.; Bopp, B. A.; Granneman, G. R. Br. J. Clin. Pharmacol. 1993, 36, 357-361. doi:10.1111/j.1365-2125.1993.tb00376.x
16. Kondo, T.; Yoshida, K.; Yamamoto, M.; Tanayama, S. Arzneim. Forsch. 1996, 46, 11-14.

17. Wada, T.; Nakajima, R.; Kurihara, E.; Narumi, S.; Masuoka, Y.; Goto, G.; Saji, Y.; Fukuda, N. Jpn. J. Pharmacol. 1989, 49, 337-349. doi:10.1254/jjp.49.337

18. Lamblin,, M.; Couture, A.; Deniau, E.; Grandclaudon, P. Tetrahedron: Asymmetry 2008, 19, 111-123. doi:10.1016/j.tetasy.2007.11.014 and references therein.

19. Zhang, L.; Kim, J. B.; Jang, D. O. Tetrahedron Lett. 2014, 55, 2654-2658. doi:10.1016/j.tetlet.2014.03.023

20. Lebrun, S.; Sallio, R.; Dubois, M.; Agbossou-Niedercorn, F.; Deniau, E.; Michon, C. Eur. J. Org. Chem. 2015, 1995-2004. doi:10.1002/ejoc.201403573 and references therein.

21. Nishimura, M.; Sugawara, N.; Nigorikawa, Y.; Inomiya, N.; Ueda, K.; Ishii, A.; Kanemitsu, N. Synthetic methods for isoindoline intermediate derivatives. Jpn. Pat. JP 2010241770, Oct 28, 2010.

22. More, V.; Rohlmann, R.; Mancheño, O. G.; Petronzi, C.; Palombi, L.; De Rosa, A.; Di Mola, A.; Massa, A. RSC Adv. 2012, 2, 3592-3595. doi:10.1039/c2ra20231j

23. Fujioka, M.; Morimoto, T.; Tsumagari, T.; Tanimoto, H.; Nishiyama, Y.; Kakiuchi, K. J. Org. Chem. 2012, 77, 2911-2923. doi:10.1021/jo300201g

24. Tiso, S.; Palombi, L.; Vignes, C.; Di Mola, A.; Massa, A. RSC Adv. 2013, 3, 19380-19387. doi:10.1039/c3ra43074j

25. Zhou, J.-Q.; Sheng, W.-J.; Jia, J.-H.; Ye, Q.; Gao, J.-R.; Jia, Y.-X. Tetrahedron Lett. 2013, 54, 3082-3084. doi:10.1016/j.tetlet.2013.03.138

26. Ye, B.; Cramer, N. Angew. Chem., Int. Ed. 2014, 53, 7896-7899. doi:10.1002/anie.201404895

27. Bisai, V.; Suneja, A.; Singh, V. K. Angew. Chem., Int. Ed. 2014, 53, 10737-10741. doi:10.1002/anie.201405074

28. Di Mola, A.; Tiffner, M.; Scorzelli, F.; Palombi, L.; Filosa, R.; De Caprariis, P.; Waser, M.; Massa, A. Beilstein J. Org. Chem. 2015, 11, 2591-2599. doi:10.3762/bjoc.11.279

29. Tiso, S.; Massa, A. J. Heterocycl. Chem. 2015, 52, 1570-1575. doi:10.1002/jhet.2170

30. Barrio, P.; Ibáñez, I.; Herrera, L.; Román, R.; Catalán, S.; Fustero, S. Chem. - Eur. J. 2015, 21, 11579-11584. doi:10.1002/chem.201500773

31. Scorzelli, F.; Di Mola, A.; Palombi, L.; Massa, A. Molecules 2015, 20 , 8484-8498. doi:10.3390/molecules20058484

32. Suneja, A.; Bisai, V.; Singh, V. K. J. Org. Chem. 2016, 81, 4779-4788. doi:10.1021/acs.joc.6b00770

33. Capobianco, A.; Di Mola, A.; Intintoli, V.; Massa, A.; Capaccio, V.; Roiser, L.; Waser, M.; Palombi, L. RSC Adv. 2016, 6, 31861-31870. doi:10.1039/C6RA05488A

34. Sallio, R.; Lebrun, S.; Schifano-Faux, N.; Goossens, J. F.; Agbossou-Niedercorn, F.; Deniau, E.; Michon, C. Synlett 2013, 24, 1785-1790. doi:10.1055/s-0033-1339487

35. Xu, L.-W.; Xia, C.-G. Eur. J. Org. Chem. 2005, 633-639. doi:10.1002/ejoc.200400619

36. Krishna, P. R.; Sreeshailam, A.; Srinivas, R. Tetrahedron 2009, 65, 9657-9672. doi:10.1016/j.tet.2009.08.021

37. Enders, D.; Wang, C.; Liebich, J. X. Chem. - Eur. J. 2009, 15, 11058-11076. doi:10.1002/chem.200902236

38. Wang, J.; Li, P.; Choy, P. Y.; Chan, A. S. C.; Kwong, F. Y. ChemCatChem 2012, 4, 917-925. doi:10.1002/cctc.201200135

39. Mahé, O.; Dez, I.; Levacher, V.; Brière, J.-F. Org. Biomol. Chem. 2012, 10, 3946-3954. doi:10.1039/c2ob25227a 
40. Lee, H.-J.; Cho, C.-W. J. Org. Chem. 2015, 80, 11435-11440. doi:10.1021/acs.joc.5b02124

41. Wang, L.; Shirakawa, S.; Maruoka, K. Angew. Chem., Int. Ed. 2011, 50, 5327-5330. doi:10.1002/anie.201101307

42. Lee, S.-J.; Bae, J.-Y.; Cho, C.-W. Eur. J. Org. Chem. 2015, 6495-6502. doi:10.1002/ejoc.201500940

43. Weiß, M.; Borchert, S.; Rémond, E.; Jugé, S.; Gröger, H. Heteroat. Chem. 2012, 23, 202-209. doi:10.1002/hc.21004

44. Guo, J.; Yu, S. Org. Biomol. Chem. 2015, 13, 1179-1186. doi:10.1039/C4OB02227K

45. Bandini, M.; Bottoni, A.; Eichholzer, A.; Miscione, G. P.; Stenta, M. Chem. - Eur. J. 2010, 16, 12462-12473. doi:10.1002/chem.201000560

46. Bandini, M.; Eichholzer, A.; Tragni, M.; Umani-Ronchi, A. Angew. Chem., Int. Ed. 2008, 47, 3238-3241. doi:10.1002/anie.200705685

47. Davies, S. G.; Garner, A. C.; Goddard, E. C.; Kruchinin, D.; Roberts, P. M.; Rodriguez-Solla, H.; Smith, A. D. Chem. Commun. 2006, 2664-2666. doi:10.1039/b604835h

48. Davies, S. G.; Fletcher, A. M.; Hermann, G. J.; Poce, G.; Roberts, P. M.; Smith, A. D.; Sweet, M. J.; Thomson, J. E. Tetrahedron: Asymmetry 2010, 21, 1635-1648. doi:10.1016/j.tetasy.2010.03.033

49. Davies, S. G.; Hughes, D. G.; Price, P. D.; Roberts, P. M.; Russell, A. J.; Smith, A. D.; Thomson, J. E.; Williams, O. M. H. Synlett 2010, 567-570. doi:10.1055/s-0029-1219346

50. Davies, S. G.; Lee, J. A.; Roberts, P. M.; Stonehouse, J. P.; Thomson, J. E. Tetrahedron Lett. 2012, 53, 1119-1121. doi:10.1016/j.tetlet.2011.12.088

51. Davies, S. G.; Huckvale, R.; Lee, J. A.; Lorkin, T. J. A.; Roberts, P. M.; Thomson, J. E. Tetrahedron 2012, 68, 3263-3275. doi:10.1016/j.tet.2011.12.084

52. Jung, M. E. In Comprehensive Organic Synthesis; Trost, B. M.; Fleming, I.; Semmelhack, M. F., Eds.; Pergamon Press: Oxford, 1991; Vol. 4, pp 30-41. and references therein.

53. Rulev, A. Y. Russ. Chem. Rev. 2011, 80, 197-218. doi:10.1070/RC2011v080n03ABEH004162

54. De, K.; Legros, J.; Crousse, B.; Bonnet-Delpon, D. J. Org. Chem. 2009, 74, 6260-6265. doi:10.1021/jo9012699

55. Wang, J.; Li, P.-F.; Chan, S. H.; Chan, A. S. C.; Kwong, F. Y. Tetrahedron Lett. 2012, 53, 2887-2889. doi:10.1016/j.tetlet.2012.03.132

56. Amara, Z.; Drège, E.; Troufflard, C.; Retailleau, P.; Joseph, D. Org. Biomol. Chem. 2012, 10, 7148-7157. doi:10.1039/c2ob25963j

57. Medina, F.; Michon, C.; Agbossou-Niedercorn, F. Eur. J. Org. Chem. 2012, 6218-6227. doi:10.1002/ejoc.201200891

58. Medina, F.; Duhal, N.; Michon, C.; Agbossou-Niedercorn, F. C. R. Chim. 2013, 16, 311-317. doi:10.1016/j.crci.2012.11.001

59. Bosica, G.; Debono, A. J. Tetrahedron 2014, 70, 6607-6612. doi:10.1016/j.tet.2014.06.124

60. March, J. Advanced Organic Chemistry: Reactions, Mechanisms and Structures, 4th ed.; Wiley-VCH: New-York, USA, 1992; 795, 1027.

61. Cai, Y.-F.; Li, L.; Luo, M.-X.; Yang, K.-F.; Lai, G.-Q.; Jiang, J.-X.; Xu, L.-W. Chirality 2011, 23, 397-403. doi:10.1002/chir.20940

62. Kolodiazhnyi, O. I. Tetrahedron 2003, 59, 5953-6018. doi:10.1016/S0040-4020(03)00911-6

63. Gelat, F.; Lebrun, S.; Henry, N.; Agbossou-Niedercorn, F.; Michon, C.; Deniau, E. Synlett 2017, 28, 225-230. doi:10.1055/s-0036-1588895
64. Gelat, F.; Coffinet, M.; Lebrun, S.; Agbossou-Niedercorn, F.; Michon, C.; Deniau, E. Tetrahedron: Asymmetry 2016, 27, 980-989. doi:10.1016/j.tetasy.2016.07.010

65. Munive, L.; Dzakuma, S. A.; Olivo, H. F. Tetrahedron Lett. 2013, 54, 1230-1232. doi:10.1016/j.tetlet.2012.12.074

66. Soloshonok, V. A.; Cai, C.; Yamada, T.; Ueki, H.; Ohfune, Y.; Hruby, V. J. J. Am. Chem. Soc. 2005, 127, 15296-15303. doi:10.1021/ja0535561

67. Masamune, S.; Choy, W.; Petersen, J. S.; Sita, L. R. Angew. Chem., Int. Ed. Engl. 1985, 24, 1-30. doi:10.1002/anie.198500013

68. CCDC 1590565: these data can be obtained free of charge from The Cambridge Crystallographic Data Centre via http://www.ccdc.cam.ac.uk/data_request/cif.

\section{License and Terms}

This is an Open Access article under the terms of the Creative Commons Attribution License (http://creativecommons.org/licenses/by/4.0), which permits unrestricted use, distribution, and reproduction in any medium, provided the original work is properly cited.

The license is subject to the Beilstein Journal of Organic Chemistry terms and conditions: (https://www.beilstein-journals.org/bjoc)

The definitive version of this article is the electronic one which can be found at: doi: $10.3762 /$ bjoc. 14.46 